Ann. Génét. Sél. anim., I973, 5 (2), 257-266.

\title{
U.S. D. A.-D. H. I. A. SIRE SUMMARIES IN A DAIRY CATTLE POPULATION UNDERGOING GENETIC CHANGE ( $\left.{ }^{(}\right)$
}

\author{
F. N. DICKINSON \\ Acting Leader, Animal Improvement Programs Laboratory, \\ Animal Physiology and Genetics Institute, \\ Agricultural Research Service, United States Department of Agriculture, \\ Beltsville, Maryland 20705, U. S. A.
}

\section{SUMMARY}

The dairy cattle populations in the United States and many other countries are undergoing the most rapid genetic improvement for yield in history. This is resulting primarily from the wide use of superior bulls through artificial insemination. As a result of the tremendous effectiveness of present sire summary procedures in identifying bulls of superior genetic merit, some of the assumptions on which these summaries are based are no longer valid. This causes some summaries to be biased.

I have described briefly two alternative sire summary procedures that the United States Department of Agriculture may adopt to eliminate these difficulties and to increase the accuracy of genetic evaluations of dairy bulls. Which procedure we ultimately adopt, depends largely on how soon each can be made operationally feasible. Both procedures would be feasible at present in countries with relatively small populations of bulls and cows and where only first records are used for genetic evaluations. Hopefully, some of the concepts that I have presented may prove useful to other countries facing the same problems that we are in their genetic evaluations. I sincerely hope that this is the start of a continuing exchange of information among those of us involved in the genetic improvement of dairy cattle.

The role of the United States Department of Agriculture (U. S. D. A) in the National Cooperative Dairy Herd Improvement Program (D. H. I. A.) and the National Sire Summary and Cow Index Programs is different from the role of similar governmental organizations in many other countries. U.S. D. A. has no direct control over the bulls which are used in artificial insemination. U.S. D. A.'s role is to obtain data from the D. H. I. A. Program, analyse these data, and publish genetic evaluations on all bulls and on registered cows so that individual dairymen, artificial insemination (AI) organizations, breed associations, and others involved in the

(i) Invited report Presented at the 23rd Annual Study Meeting of the European Association for Animal Production, Commission of Animal Genetics, Verona, Italy, October 8, 1972. 
agri-business complex have accurate and objective information on the transmitting ability of bulls and cows. The artificial insemination industry consists of 26 private or cooperative organizations which are in competition with one another in various parts of the country. These organizations breed approximately 50 percent of the cow population. The U.S.D.A.-D.H.I. A. Sire Summaries and Cow Indexes are accepted as the official evaluation of genetic transmitting ability in the United States and as such are the standard reference for genetic merit.

The basic goals of artificial insemination in most countries are the same today as they were when AI became generally available to dairymen 20 to 30 years ago. These basic goals are to provide the best germ plasm for yield and other economically important traits to the largest number of dairymen at the lowest possible cost. However, these basic goals have been considerably refined in the past few years in most countries. Dairymen are now demanding more accurate information on yield and on other traits that affect a cows profitability. In the United States this has been due at least in part to the direct relationship which has been shown to exist between a bull's Predicted Difference and the income over feed cost of his daughters as well as other economically important traits (MCDANIEL, DICKINSON and MCDOWELL, I968).

The U.S. D. A. started providing genetic evaluations of dairy bulls in the midI930's. From the origin of this program until Ig62 variations of the basic daughterdam comparison were used to estimate genetic transmitting ability. In I962, the daughter-dam comparison was abandoned in favor of the more accurate herdmate comparison procedure. The present United States Department of Agriculture-Dairy Herd Improvement Association (U. S. D. A.-D. H. I. A.) Sire Summary Procedures were adopted in I967. For approximately five years prior to that time, a rudimentary herdmate comparison had been used based on as few as five daughters, and using an adjusted herdmate comparison based on a five month breedyear-season national average and an average regression for the number of daughters of $\frac{n}{n+20}$. The following changes were made in 1967 :

I) The number of daughters was accounted for. 2) The environmental correlation of half sibs within herds was included by accounting for the distribution of daughters over herds. 3) The herdmate average was adjusted for the number of herdmates using the regional-breed-year-season average yield. 4) More accurate mature-equivalent age correction factors were adopted. 5) Ten daughters were required for a bull to be summarized. Since I962, an average adjustment for the genetic level of the herd has been made by crediting the daughter-herdmate deviation with one-tenth of the difference between the herdmate average and the breed average. U. S. D. A.-D. H. I. A. Sire Summary procedures are described in the sire summary book published annually (DICkINSON, MCDANIEL, Norman and KING, I972). The Predicted Difference formula along with background information and examples has been given by FOLEY, BATH, DICKINSON and TUCKER, I972).

In order to calculate unbiased sire summaries using our present procedures, the following assumptions must be met.

I. All sires and dams represented in the summary are random samples of the genetic merit of one overall population.

2. There is no genetic trend in the population. 
3. There is no differential culling among the daughters of the bull versus their herdmates.

4. The bull's daughters receive no preferential treatment over their herdmates.

These assumptions were all quite reasonable when originally adopted. However, assumptions I and 2 have become less and less tenable over the past five years until at the present time, they have become a serious concern. There is evidence of a steadily increasing rate of genetic progress (MCDANIEL and KING, I972). This causes summaries to decrease as bulls are repeatedly evaluated over a period of several years. To make matters more difficult, the rate of genetic progress does not appear to be constant between regions of the country. This is because : some AI studs have bulls of higher genetic merit than others, and dairymen in some regions make heavier use of genetically superior bulls than in other regions. Assumptions 3 and 4 are not serious problems. Assumption 3 can be largely eliminated by better sire summary procedures. Assumption 4 will probably always continue to be a problem in a few sire summaries but is becoming less of a problem as time progresses.

Approximately two years ago, our U.S. D. A. group embarked on a series of investigations intended to eliminate the necessity of making assumptions I and 2 in the U. S. D. A.-D. H. I. A. Sire Summaries. At about the same time Dr C. R. HENDERSON of Cornell University announced the implementation of a new sire summary procedure known as the Direct Comparison Method. He described his procedure at that time as a generalized least-squares method whereby direct comparisons were made among the daughters of AI bulls utilizing their first records. Because of U. S. D. A.'s responsibilities to the entire dairy industry of the United States, the restrictions in Dr HENDERSON's method at that time of summarizing only AI bulls and using only first records, made it impossible to adopt his metholology for our use. Therefore, U.S. D. A. set out to modify present herdmate procedures in order to eliminate assumptions I and 2. We did this for several reasons :

I) we realized that improvements were needed in our procedures as soon as possible ; 2) we had no idea when Dr HENDERSon's method might be developed to the point where it would be usable under our conditions ; 3) the herdmate comparison method was operationally possible on existing computers and we were quite certain that improvements could be made in it which would eliminate current biases.

Although we have been cooperating with Dr HENDERSON on sire summary work for the past several years, the research on these two different methods has been conducted more or less independently. Therefore, it appears at the present time that U.S. D. A. has two alternative procedures which may be developed in the foreseeable future to make improvements in the accuracy of the U.S.D.A.D. H. I. A. Sire Summaries.

\section{DIRECT COMPARISON METHOD OF SIRE EVALUATION}

At present, Dr HENDERson prefers calling his method Best Linear Unbiased Prediction rather than generalized least-squares. The basis for this method as presently used is the following mathematical model :

$$
\mathrm{Y}_{i j k l}=\mu+h_{i}+g_{j}+s_{j k}+e_{i j k l},
$$


where : $\mathrm{Y}_{i j k l}$ is the age-corrected first lactation yield of the $l$-th daughter of sire $k$ in sire-group $j$ made in herd-year -season $i, \mu, h_{i}$ and $g_{j}$ are fixed effects and $s_{j k}$ and $e_{i j k l}$ are random effects. Since only one record per cow is used, cow effects cannot be estimated and therefore are not included in the model.

As can be seen from the model, differences among sires are estimated in this method by comparing the first lactation yield of the daughters of one sire with that of contemporary daughters of other sires on a within herd-year-season and sire-group basis. Thus, sires may be compared to one another directly, or they may be compared indirectly through comparisons with other sires. This method, as do other methods of sire evaluation, actually gives information on differences among sires rather than absolute estimates of their genetic transmitting ability. In this case, assuming that the mathematical model is truly appropriate for the biological situation and the ratio of variance components is known, this method should give the best unbiased predictions of sire differences from the available data.

Basically, the computational procedures are as follows (LENTZ, MILLER and HENDERSON, I97I). Sires which are to be compared are categorized into sire-groups. Unproven sires should be placed in different groups from the proven sires and the proven sires are best divided into different groups on some logical basis, for example, AI organization. The more sires which are included with large :numbers of AI daughters in many different herds, the better are the ties among herds and therefore, in general, the better are the estimates of sire differences. The first records on daughters of these sires are sequenced by herd-year-season (HYS). Two fixed seasons are used in each year, December through April and May through November.

Since each HYS equation is completed before the next one is begun, each may be absorbed into the sire equations as soon as it is completed; thus, greatly reducing the amount of core storage required of the computer. In addition, the sire-group equations can be obtained later by summing the coefficients for the individual sires in each group and therefore do not need to be dealt with during the initial collection and absorption of the HYS equations. Basically, it is these techniques which make the procedure computationally feasible for large numbers of bulls on existing computers.

Up to this point in the calculations the sire within sire-group effects $\left(s_{j k}\right)$ have been treated as through they are fixed rather than random as specified by the model. Values for these random variables are estimated by best linear prediction (selection index) methods by adding the variance ratio $\left(\sigma^{2} e / \sigma_{s}^{2}\right)$ to the diagonal element of each sire equation. The variance ratio may be different for each sire group. Adding the ratio breaks the dependency between the group equation and the sire equations within the group. A dependency still exists between the group equations and the absorbed HYS equations and a restriction is needed to obtain a unique solution. Dr HENDERSON has proposed the use of a Lagrange Multiplier equation to eliminate this depencency. This Lagrange Multiplier equation permits one to specify the desired value of any linear function of the solutions, thereby enabling one to maintain a constant base from year to year to compare subsequent evaluations on the same animal.

At the present time we anticipate working closely with Dr HENDERSON on further developments to this methodology which will permit summarizing very large numbers of sires, including natural service sires, utilizing all available records 
on the daughters on each sire and accouting for the intra-herd correlation among each sire's daughters. As of this writing Dr HENDERSON has developed a procedure for summarizing natural service bulls and this procedure has been programmed by his coworkers. Work is progressing at present to test out this development. Procedures to include all available lactation records remain to be worked out and U. S. D. A. research geneticists, Dr H. Duane NoRman and Dr Jeffrey F. KEOwn, will work closely with Dr. HENDERSON on this. Needless to say, using multiple records per cow will complicate this procedure greatly as well as increasing the amount of computer time significantly. It will require the addition of a cow effects term to the model. Therefore, many of the presently diagonal submatrices will become non-diagonal, resulting in a great increase in the computer time required to process them.

\section{U. S. D. A. MODIFIED CONTEMPORARY COMPARISON ME'THOD}

\section{Genetic Level of Herdmates and Genetic Trend}

As indicated previously, our approach to eliminating assumptions I and 2 was to make improvements to the herdmate comparison method which we knew would be operationally feasible when completed. As a result of work by U.S. D. A. research geneticists Dr Ben 'T. MCDANIEL and Dr H. Duane Norman it appears that adjusting the herdmate comparison for the genetic level for the herdmates' sires and running repeated iterations of these summaries should largely eliminate biases due to the genetic level of herdmates and genetic trend. These procedures should give a very close approximation to the true least-squares solutions for transmitting ability. The basic modification to the daughter-herdmate deviation formula is as follows.

The present U.S.D.A.-D.H.I.A. herdmate comparison is calculated :

(Daughter average - adjusted herdmate average) + o.I (adjusted herdmate average - breed average).

In simple terms, including an adjustment for the genetic level of the herdmates' sires would change this to :

(Daughter average - herdmate average + average genetic merit of herdmate sires).

Thus, the " average " correction for the genetic level of the herd in the present formula is replaced in the new procedures by a correction for the individual sire of each herdmate.

The key to eliminating genetic bias at a given point in time using this method, and also to eliminating genetic bias across time (due to genetic trend) is to obtain improved estimates of the average genetic merit of the herdmate sires through iteration. It has been shown empirically by Dr NORMAN that correcting sire summaries for the genetic level of herdmate sires through iteration should eliminate the major known bias in the present procedures. Therefore, both the correction for the genetic merit of the herdmate sires and repeated iterations of the solutions for transmitting ability are necessary to approach the least-squares solution ; i.e., the unbiased estimate of transmitting abilities of the sires summarized. 
In addition to this major change in procedures, there are a number of other improvements which could be made to increase the accuracy and completeness of sire summaries utilizing the herdmate comparison procedure.

\section{Pedigree Information}

Pedigree information can be incorporated into these summaries. This would initially include only the bulls' sire and maternal grand sire. The cost of incorporating information from the female side of the pedigree would obviously be much greater than that from the male side. Evidence is accumulating (BUTCHER, I972) that indicates there is little additional information gained from the dam's side of the pedigree if reasonably good estimates of the sire's and maternal grand sire's transmitting ability are available. The procedure utilized in New Zealand has been modified by Dr Norman for use in this system. It appears that the most effective use of pedigree information for our purposes is to use it as a basis for grouping. This would mean regressing the daughter-herdmate deviations on the group means using the Repeatability of the sire summary according to the formula :

Predicted Difference $=$ Group Mean $+\mathrm{R}$ (Daughter-Herdmate Deviation - Group Mean).

When little information is available on progeny the pedigree data is quite important relative to the progeny information and should materially increase the accuracy of the first several summaries on a bull.

\section{Modified Contemporary Comparison}

There has been some concern in our country and in other countries as well, that the use of later records ; $i$. e., records made by cows that have survived culling, would cause bias in sire summaries. It now appears that whatever bias there was from the use of all records arose in large part because of inappropriate age correction factors. The new factors, that will shortly be released, were developed by a procedure devised by Dr P. D. Milier (Miller, I97I). These factors should decrease the effect of culling bias from later records when they are used in conjunction with first records, and therefore should make the use of all available records a more valuable procedure than before.

As a further safety factor against biasing sire summaries from the use of selected records or age factors which are not appropriate for a particular herd, Drs McDANIEL and NoRman have developed a modified contemporary comparison procedure which makes the greatest use of the herdmate records which are contemporary to the daughter records. The formulas that would be used to calculate the modified contemporary averages for first records of daughters and for later records of daughter ; $i$. e., records other than first records, are as follows :

Modified Contemporary average for daughters' first records $=\frac{N_{c}(\overline{\mathrm{C}})+\mathrm{W}_{\mathrm{L}}\left(\overline{\mathrm{HM}}_{\mathrm{L}}\right)}{\mathrm{N}_{c}+\mathrm{W}_{\mathrm{L}}}$

where $\mathrm{N}_{c}$ is the number of first lactation contemporary records, $\overline{\mathrm{C}}$ is the mean of first lactation herdmate records, $W_{\mathrm{L}}$ is a weighting factor for the number of later 
lactation herdmate records, and $\overline{\mathrm{HM}}_{\mathrm{L}}$ is the mean of the later lactation herdmate records.

Modified Contemporary average for daughters' later records $=\frac{\mathrm{N}_{L}\left(\overline{\mathrm{HM}}_{\mathrm{L}}\right)+\mathrm{W}_{c}(\overline{\mathrm{C}})}{\mathrm{N}_{\mathrm{L}}+\mathrm{W}_{c}}$ where $\overline{\mathrm{HM}}_{\mathrm{L}}$ and $\overline{\mathrm{C}}$ are the same as for the first record formula, $\mathrm{N}_{L}$ is the number of later lactation herdmate records and $\mathrm{W}_{c}$ is a weighting factor for the number of first lactation herdmate records. Thus, for all daughter records the greatest emphasis would be placed on the daughter - "herdmate " comparisons which in general should be most accurate; $i$. e., first records versus first records and later records versus later records.

\section{Additional Comments on the Use of Second and Later Lactation Records}

In spite of the fact that most countries of the world use only first lactation records in sire summaries, we continue to believe that more accurate summaries can be calculated by also using later records. We believe that the evidence for this is considerable and we intend to continue using later records in whatever revisions we make to our sire summary system. The greatest single reason for this decision is the large amount of data which would be lost from the sire summaries under a first record contemporary comparison in our country. MCDANIEI, NORMAN and DickINson (I972) have shown the following percentage losses of AI bull's daughters in the various breeds : Ayrshire I4 p. I0o; Guernsey, 9 p. Ioo; Holstein, 6 p. Ioo; Jersey, 9 p. Ioo ; Brown Swiss, 23 p. Ioo. If AI-sired first lactation contemporaries are required, as in the Direct Comparison Method presently used the losses of daughters are even higher: Ayrshive, 22 p. Ioo; Guernsey, I8 p. Ioo; Holstein, 9 p. roo; Jersey, 20 p. Ioo; Brown Swiss, 34 p. Ioo. These daughters would be lost from the sire summaries because they would not have first lactation contemporaries available in the same herd-year-season although they would have herdmates. We strongly feel that this loss of data would result in a net decrease in the accuracy of our summaries especially in view of the more accurate age correction factors which will be adopted in the near future and the modified contemporary comparison which would permit differential weighting of different records.

\section{Standardizing Records to a Common Age}

It appears to us that other countries could also gain an increase in accuracy in sire evaluation work if they would start using later records. At any rate, even if they continue to use only first records, there appears to be little justification for doing so without standardizing these to a common age such as average age of first calving. The ages of first calving, which vary generally from 22 or 23 months up to about 34 or 35 months are the ages at which the greatest change in yield takes place as age increases. Therefore, even a few months difference between the average calving age of daughters of one bull and the average calving age of daughters of another bull could cause a serious bias in the genetic evaluation. With relatively small amounts of data the procedures developed by Dr MILLER for calculating age factors 
could be used in almost any country without difficulty. Therefore, I would make a strong recommendation that all countries give serious consideration to standardizing the lactation records used in sire summaries for age at calving. even if only first records are utilized. With a relatively small geographical area it might be possible to use a single set of factors for an entire country for each breed and trait. In our case the problem is considerably more difficult because of the wide differences in climate and management which are found in different parts of the country. In fact, we will have to use eleven different sets of regional factors to standardize HolsteinFriesen records. We will also adopt separate sets of factors to standardize milk yield, fat yield, and fat percent. We intend to eliminate the mature-equivalent concept and to age-correct all lactation records to the age of average production which in our case is approximately 42 months for each breed. If you are using only first records it probably makes more sense to age-correct to the average age of first calving which in our case would be approximately 27 months of age.

\section{Number of Herdmates and Number of Independent Herdmates}

On the average, the greater the number of herdmates available the more accurate is the daughter-herdmate deviation. Under our present system the number of herdmates is not taken into account and all daughter-herdmate comparisons are weighted equally. Dr Norman has developed a procedure whereby herdmate comparisons based on a larger number of herdmates would receive more weight and also herdmate comparisons from the same herd that were based on different sets of herdmates would receive greater weight than those based on the same herdmates. This will increase the accuracy of the sire summaries because multiple herdmate comparisons from the same herd-year-season very likely contain many of the same herdmates and are therefore all subject to any sampling problems peculiar to that particular group of herdmates. Two other factors which are taken into account are the number of different sires represented among the herdmates and the average Repeatability of the Predicted Differences of these herdmate sires. Both of these factors would affect the accuracy of each daughter-herdmate deviation adjusted for the average genetic merit of the herdmate sires.

\section{Adjusting for Residual Herd Effects}

In most present sire summary procedures, each daughter with the same number of records receives equal weight in the calculation of the daughter-herdmate deviation regardless of the distribution of daughters across herds. This procedure fails to account for the within and between herd variances properly when daughters are unevenly distributed across herds. In fact, the present U. S. D. A.-D. H. I. A. prccedure is one of the few that gives any consideration to the environmental correlation among daughters within a herd. To correct this deficiency, Dr. Norman has devised a procedure utilizing the within and between herd variances which gives greater weighting to daughters which are in herds that have fewer numbers of daughters (Norman, McDaniei, and Dickinson, I972).

Our present procedure of weighting every daughter the same regardless of how many there are per herd, leads to a large number of daughters in a single herd domi- 
nating a sire summary. It takes a very large number of daughters in other herds to counteract the effect of this group of daughters in a single herd. Under the new procedure this deficiency would be eliminated. No matter how many daughters there are in a herd they could not count more than approximately 9.5 daughters distributed one per herd. This will also eliminate the present situation whereby the addition of more daughters in a herd that already has a large number of daughters can actually cause the repeatability value to decrease.

\section{Preliminary Sire Summaries}

It is apparent that in the United States, one of the most serious obstacles to more rapid genetic improvement in dairy cattle is that not enough potentially superior bulls are being progeny tested. One way to overcome this deficiency is to obtain sire summaries earlier in bulls' lives so that semen can be saved from the apparently superior bulls and the apparently inferior ones can be eliminated. U.S. D. A. will try to help speed up genetic progress by calculating preliminary sire summaries based on records in progress. We will commence to do this as soon as details can be worked out to acquire the necessary records in progress from the II dairy records processing centers throughout the country. These records in progress will be projected to 305 days in milk and the projected records will be weighted according to the length of the record in progress. The preliminary summaries will make it possible to screen bulls between 6 months and a year earlier than is now possible. This will be a screening process only, in that it will be possible to identify those bulls that appear to be either very superior or very inferior. The AI studs can then start banking semen on the superior bulls and can eliminate the infericr ones. It is estimated that the lead time in banking semen from superior bulls would result in approximately 25000 additional doses of semen from each of these bulls. These preliminary sire summaries will have two important financial benefits : I) dairymen will have many more highly profitable cows from the additional semen from these seperior bulls, and 2) AI studs will derive considerable additional profit from the sales of this semen, thus enabling them to progeny test larger numbers of bulls.

Reçu pour publication en novembre 1972.

\section{RÉSUMÉ}

L'INDEXATION U.S. D. A.-D. H.I. A. DES TAUREAUX

DANS UNE POPULATION DE BOVINS LATTIERS EN PROGRÈS GÉNÉTIQUE

Les populations de vaches latières des États-Unis et de beaucoup d'autres pays sont en train d'effectuer le progrès génétique sur la production la plus rapide de leur histoire. Ceci résulte essentiellement de l'utilisation intensive d'excellents taureaux grâce à l'insémination artificielle. Le succès remarquable des méthodes actuelles d'indexation des mâles pour la détection des taureaux de niveau génétique supérieur a fait que certaines hypothèses sur lesquelles reposent ces index de sélection ne sont plus valides. Certains index en viennent à être biaisés.

J'ai décrit succinctement deux méthodes d'indexation des taureaux que le Ministère de l'Agriculture des États-Unis (U. S. D. A.) pourrait adopter pour éliminer ces difficultés et pour 
accroître la précision du jugement du niveau génétique des taureaux laitiers. La méthode qui sera finalement adoptée sera pour une grande part, celle qui pourra être mise en application la première. Les deux méthodes pourraient être appliquées dès maintenant aux pays à faible effectif en taureaux et vaches et où les seuls résultats de la première lactation sont utilisés pour le jugement des taureaux. Il est à souhaiter que certains concepts que j'ai présentés puissent se révéler utiles aux autres pays confrontés aux mêmes problèmes que nous pour l'évaluation des niveaux génétiques. J'espère sincèrement que pour ceux d'entre nous qui participent à l'amélioration génétique des bovins laitiers, nous sommes au début d'un échange continuel d'information.

\section{ZUSAMMENFASSUNG}

\section{U. S. D. A.-D. H. I. A.-STIEREN-PRÜFUNGEN \\ IN MILCHVIEHPOPULATIONEN MIT GENETISCHEM TREND}

Die Milchviehpopulationen in den Vereinigten Staaten und in vielen andern Ländern machen die schnellsten genetischen Leistungsverbesserungen in ihrer Geschichte durch. Dies ist in erster Linie das Resultat der umfangreichen Benützung überlegener Stiere durch die künstliche Besamung. Als Resultat der enormen Wirksamkeit gegenwärtiger Stieren-Prüfungs-Verfahren für die Ermittlung von Stieren mit überlegenem Zuchtwert sind einige Annahmen, auf denen diese Verfahren beruhen, nicht mehr gültig. Dies beeinflusst teilweise die Ergebnisse.

Ich habe zwei verschiedene Verfahren beschrieben, die das Landwirtschaftsdepartement der Vereinigten Staaten zur Verhinderung dieser Schwierigkeiten und zur Verbesserung der Genauikeit in der Zuchtwertschätzung für Milch bei Stieren anstrebt. Welches Verfahren wir annehmen werden hängt weitgehend davon $a b$, wie bald es technisch durchführbar wird. Beide Verfahren wären gegenwärtig möglich in Ländern mit relativ kleinen Beständen an Stieren und Kühen und wo nur Erstlaktationen für die Zuchtwertschätzung verwendet werden. Ich hoffe, dass einige der Konzepte, die ich dargelegt habe, auch für andere ändere nützlich sind, die gleiche Probleme bei ihrer Zuchtwertschätzung haben. Es ist mein aufrichtiger Wunsch, dass dies der Beginn eines fortwährenden Informationsaustausches ist, unter denen von uns, die sich mit der gentischen Verbesserung des Milchviehs befassen.

\section{RÉFÉRENCES BIBLIOGRAPHIQUES}

Butcher K. R., I972. Unpublished Ph. D. Thesis research. North Carolina State University, Raleigh.

Dickinson F. N., McDaniel B. T., Norman H. D., King G. J., rg7z. U. S. D. A.-D. H. I. A. Sire Summary List, May I972. Introductory material. ARS 44-242, U. S. Department of Agriculture.

Foley R. C., Bath D. L., Dickinson F. N., Tucker H. A., I972. Dairy Cattle: Principes, Practices, Problems, Profits. Lea and Febiger, Philadelphia, Pennsylvania, 693 pp.

Lentz W. E., Miller P. D., Henderson C. R., 1971. Evaluating dairy sires by direct comparison. Unpublished mimeograph.

McDaniel B. T., Dickinson F. N., McDowell R. E., 1968. Regression of daughter characteristics on sire's predicted difference. J. Dairy Sci., 51, 986.

McDaniel B. T., King G. J., I972. Milk and fat yield differences for registered cows sired by artificial and natural insemination. J. Dairy Sci. In Press.

McDaniel B. T., Norman H. D., Dickinson F. N., 1972. Herdmates versus contemporaries for evaluating progeny tests of dairy bulls. $J$. Dairy Sci. In Press.

MILLER P. D., I97r. Estimating the effect of season and age of calving. Paper presented at 66 th Annual Meeting, American Dairy Science Association, East Lansing, Michigan.

Norman H. D., McDaniel B. T., Dickinson F. N., I972. Sire evaluation : A herdmate comparison that weights yield using daughters' distribution across herds. J. Dairy Sci. In Press. 